\title{
The effect of combination of hemofilter, pre- and intraoperative methylprednisolone administration on systemic inflammatory response syndrome (SIRS) post open heart surgery
}

\author{
Supomo ${ }^{1 *}$, Teguh Aryandono ${ }^{2}$, Marsetyawan Soesatyo ${ }^{3}$, Paulus Sudiharto ${ }^{4}$ \\ ${ }^{1}$ Thoracic and Cardiovascular Surgery Division, ${ }^{2}$ Oncologic Surgery Division, Department of \\ Surgery, ${ }^{3}$ Department of Histology and Cell Biology, ${ }^{4}$ Neuro Surgery Division, Department \\ of Surgery, Faculty of Medicine/Dr. Sardjito General Hospitall, Universitas Gadjah Mada, \\ Yogyakarta
}

DOI: http://dx.doi.org/10.19106/JMedSci004901201702

\section{ABSTRACT}

Systemic inflammatory response syndrome (SIRS) occurs in almost all patients whom undergo open heart surgery causes the increase its morbidity and mortality. The effect of pre- and intraoperative methylprednisolone administration combined with hemofilter application in cardiopulmonary bypass machine in the reduction of SIRS incidence remains controversial. This study aimed to evaluate the effect pre- and intraoperative methylprednisolone administration combined with hemofilter on SIRS incidence after open heart surgery. This was an experimental study using prospective randomized openblinded evaluation (PROBE) design. Ninety-five patients from Dr. Sardjito General Hospital, Yogyakarta, and Dr. Cipto Mangunkusumo General Hospital, Jakarta, who had open heart surgery within the period of December 2011 to May 2012 were enrolled in this study. The patients were randomly allocated into two groups i.e. Group A (48 patients) received pre-; intra-; and postoperative methylprednisolone $(15 ; 5$ and $5 \mathrm{mg} / \mathrm{kg} \mathrm{BW}$, respectively) and hemofilter and Group B (47 patients) just received intra- and postoperative methylprednisolone (15 and $5 \mathrm{mg} / \mathrm{kg}$ BW). The SIRS incidence was evaluated in 3; 24; 48 and 72 hours post surgery. This study showed that the SIRS incidence in Group B at $3(\mathrm{OR}=0.12 ; 95 \% \mathrm{Cl}=0.03-0.39 ; \mathrm{p}<0.001)$ and $24(\mathrm{OR}=0.38 ; 95 \% \mathrm{Cl}=0.14$ $0.996 ; p<0.031)$ hours postoperative were significantly higher than that in Group A. In conclusion, pre- and intraoperative methylprednisolone administration combined hemofilter significantly decrease the SIRS incidence post open heart surgery.

\section{ABSTRAK}

Systemic inflammatory response syndrome (SIRS) terjadi pada hampir semua pasien yang menjalani bedah jantung terbuka sehingga menyebabkan meningkatnya morbiditas dan mortalitas. Pemberian metilprednisolon pra- dan intraoperatif bersama hemofilter pada mesin cardiopulmonary bypass masih kontroversial dalam mengurangi risiko SIRS. Penelitian ini bertujuan untuk mengkaji efek pemberian metilprednisolon pre- dan 
Supomo et al., The effect of combination of hemofilter, pre- and intraoperative methylprednisolone administration on systemic inflammatory response syndrome (SIRS) post open heart surgery

intraoperasi bersama penggunaan hemofilter terhadap kejadian SIRS paska bedah jantung terbuka. Penelitian ini merupakan penelitian eksperimental dengan rancangan prospective randomized open-blinded evaluation (PROBE). Sebanyak 95 pasien yang menjalni bedah jantung terbuka di RSUP Dr. Sardjito, Yogyakarta dan RSUPDr. Cipto Mangunkusumo, Jakarta, selama Desember 2011 hingga Mei 2012 diikutsertakan dalam penelitian ini. Pasien dibagi menjadi 2 kelompok yaitu Kelompok A (48 pasien) menerima metilprednisolon pre-, intra- dan pascaoperasi dengan dosis berturut-turut 15,5 dan $5 \mathrm{mg} / \mathrm{kg}$ BB serta Keompok B menerika metilprednisolon intra- dan pascaoperasi dengan dosis $15 \mathrm{dan} 5 \mathrm{mg} /$ kg BB. Kejadian SIRS diamati pada jam ke 3, 24, 48 dan 72 pascaoperasi. Hasil penelitian menunjukkan kejadian SIRS pada Kelompok B pada 3 jam $(\mathrm{OR}=0,12 ; 95 \% \mathrm{Cl}=0,03-0,39$; $\mathrm{p}<0,001)$ and 24 jam $(\mathrm{OR}=0,38 ; 95 \% \mathrm{Cl}=0,14-0,996 ; \mathrm{p}<0,031)$ pascaoperasi lebih tinggi secara bermakna dibandingkan pada Kelompok A. Dapat disimpulkan, pemberian metilprednisolon pre- dan pascaoperasi bersama dengan penggunaan hemofilter secara bermakna menurunkan kejadian SIRS pasa operasi jantung terbuka.

Keywords : hemofilter - methylprednisolone - SIRS - open heart surgery - adverse event

\section{INTRODUCTION}

Open heart surgery is well-accepted treatment for ischemic, valvular or congenital heart diseases, with low morbidity and mortality. Although it is fundamental for most heart opertions, it is associated with a complex Systemic Inflammation Response Syndrome (SIRS). The SIRS occurs in almost all patients whom undergo open heart surgery. ${ }^{1-3}$ The clinical course of SIRS varies greatly and is often difficult to predict. ${ }^{1}$ Sometimes with subtle SIRS can be clinically harm the patients. ${ }^{4}$ Moreover, patients with SIRS can progress to sepsis, septic shock, and may progress to multi-organ failure, which progression into death. ${ }^{1,2,5}$

To prevent the SIRS incidence after open heart surgery, intraoperative methylprednisolone administration is performed by mixed in a liquid circuit priming cardiorespiratory machine before the blood circulation outside the body started. The intraoperativemethylprednisoloneadministration in open heart surgery was first introduced by Raploge et al. ${ }^{6}$ in 1966. Furthermore, it is used as a standard protocol to prevent SIRS due to the use of cardiopulmonary bypass machine. ${ }^{7}$
However, further studies demonstrated the limitations of this protocol. The widespread use of corticosteroids to prevent detrimental physiologic alterations associated with activation of the SIRS on patients undergoing open heart surgery has been reported. However, the clinical evidences of the use corticosteroids to prevent the decline pulmonary function and to improve the systemic edema does not support. In contrast, the use corticosteroids can increase postoperative blood glucose levels and prolong the surgical wound healing lead to morbidity and mortality can not be minimized. ${ }^{8}$ In addition, the ability of steroids to improve clinical outcomes in pediatric cardiac surgery patients was less clear and may actually be harmful. ${ }^{9,10}$

To overcome the limitations of the intraoperative methylprednisolone use to prevent SIRS, some protocols have been applied. A protocol using combination of intraoperative and preoperative methylprednisolone administration to reduce of the SIRS incidence after open heart surgery has been developed and used. Furthermore, the use of hemofilter in cardiopulmonary bypass machine has been initiated in 1980s. Hemofiltration during open 
heart surgery served as an effective method for increased red blood cells and plasma protein concentration and for allowing volume and edema control. ${ }^{11}$ The use of hemofilter reduced post-cardiopulmonary bypass inflammatory response and immunologic activation associated with improvements in postoperative pulmonary, cardiac and neurologic function. ${ }^{12,13}$ In this study we reported the effect of combination between preoperative and intraoperative methylprednisolone administration as well as the use of hemofilter on the incidence of postoperative SIRS on patients underwent open heart surgery.

\section{MATERIALS AND METHODS}

\section{Patients and study design}

This was an experimental study with Prospective Randomized Open-Blinded Evaluation (PROBE) design conducted in Dr. Sardjito General Hospital, Yogyakarta and Dr. Cipto Mangunkusumo General Hospital, Jakarta during the period of December 2011 until May 2012. The subjects were all patients who aged more than 18 years old, had an heart defect, underwent open-heart surgery and patients as well as their family were willing to participate in this study by signing an inform consent. Patients with a heart defect who had a chronic pulmonary diseases, ever underwent lung surgery, ever underwent aorta thoracalis surgery, ever underwent open heart surgery and abnormal left ventricular function were excluded from this study. The subjects were randomly allocated into two groups i.e. Group A were the patients who treated with pre-; intra-; and postoperative methylprednisolone (15; 5 and $5 \mathrm{mg} / \mathrm{kg}$ BW, respectively), preand postoperative methylprednisolone (5 $\mathrm{mg} / \mathrm{kg} \mathrm{BW}$ ), and hemofilter and Group B were the patients who treated with intraand postoperative methylprednisolone (15 and $5 \mathrm{mg} / \mathrm{kg}$ BW, respectively). Protocol of the study was approved by the Medical and Health Research Ethics Committee, Faculty of Medicine, Universitas Gadjah Mada/ Dr. Sardjito General Hospital, Yogyakarta (\#KE/FK/768/EC) and Faculty Medicine/ Dr. Cipto Mangunkusumo General Hospial, Universitas Indonesia, Jakarta (\#364/PT02. FK/ETIK/2012).

\section{Protocol of study}

After approval by the ethics committee and written informed consent, the eligible patients undergoing open heart surgery were enrolled in the study. After premedication with medazolam $0.05 \mathrm{mg} / \mathrm{kg}$ BW, fentanyl $1 \mu \mathrm{g} /$ $\mathrm{kg} \mathrm{BW}$, dobutamine $5-10 \mu \mathrm{g} / \mathrm{kg} \mathrm{BW} / \mathrm{min}$ and nitroglycerin $0.5 \mu \mathrm{g} / \mathrm{kg} \mathrm{BW} / \mathrm{min}$ for patients undergoing coronary bypass surgery, general anesthesia was induced with etomidate lipuro 0.2-0.4 mg/kg BW and rocuronium 0.5-0.6 $\mathrm{mg} / \mathrm{kg} \mathrm{BW}$ as muscle relaxant. Anesthesia was maintained by continuous intravenous infusion of propofol $1 \mathrm{mg} / \mathrm{kg} \mathrm{BW} / \mathrm{h}$ and fentanyl $2 \mu \mathrm{g} /$ $\mathrm{kg}$ BW. Right before induction, the patients of Group A were administered preoperative intravenous methylprednisolone $5 \mathrm{mg} / \mathrm{kg}$. The ECG, EEG, arterial blood oxygen saturation, pulmonary artery pressure, aesophageal and rectal temperature and arterial blood pressure were monitored continuously by using Marquette Solar 8000 Patient Monitor.

After induction, the patients of both groups (Group A and B) were administered intraoperative intravenous methylprednisolone $15 \mathrm{mg} / \mathrm{kg} \mathrm{BW}$ by mixing with priming fluid of heart-lung machine. Furthermore, hemofilter device was attached to heart-lung machine circuit and activated when the rewarming process had been conducted for the patients of Group A. The amount of fluid aspirated from the intravascular space was $15 \mathrm{~mL} / \mathrm{kg}$ 
BW. Open heart surgery was performed in a standardized fashion in the hospitals. After the surgery, all patient of both groups (Group A and B) were administered postoperative methylprednisolone intravenous $5 \mathrm{mg} / \mathrm{kg}$ BW for 48 hour. Blood samples of the both groups were collected before the surgery for hemoglobin, ureum, creatinine, albumin, blood glucose, kalium, natrium, calcium, and magnesium levels baseline examinations. The white blood cell and neutrophil counts were also examined from preoperative blood samples. Furthermore, it was continously collected in 3; 24; 48 and 72 hours post surgery for white blood cell count, neutrophil and $\mathrm{PaCO}_{2}$ examinations.

The SIRS incidence was evaluated in 3; 24; 48 and 72 hours post surgery. The diagnosis of SIRS was made if the subject met two or more of these criterias followed 1) body temperature less than $36^{\circ} \mathrm{C}$ or more than $38^{\circ} \mathrm{C}$; 2) heart rate greater than 90 beats per minute; 3) respiratory rate more than 20 breaths per minute or $\mathrm{PaCO}_{2}$ less than $32 \mathrm{mmHg}$, and white blood cell count greater than 12000 cell/ $\mathrm{mm}^{3}$ or neutrophil count increased more than $10 \%$ from its normal value.

\section{Statistical analysis}

Data were presented as mean \pm standard deviation (SD) and compared using analysis of variance (ANOVA) continued using t-test for parametric data. For non-parametric data were compared using Chi-square or Fisher exact test. Significant difference was defined as $\mathrm{p}<0.05$

\section{RESULTS}

Ninety-six patients who met inclusion and exclusion criteria were recruited during the study. However, one of the patients was not analyzed due to the data were not complete. Furthermore, 48 patients of the Group A, and 47 patients of the Group B were analyzed. The characteristics of the patients of the both group were not significantly different ( $\mathrm{p}$ $>0.05$ ) (TABLE 1).

The SIRS incidence in the both groups was evaluated at 3, 24, 48, and 72 hours postoperative. The SIRS incidence in the Group A was significantly lower than that in Group B at 3 and 24 hours postoperative ( $<<$ 0.01) (TABLE 2 and 3). However, the SIRS incidence in Group A was not significantly different compared to that in Group B at 48 and 72 hours postoperative $(\mathrm{p}>0.05)$ (TABLE 4). It was demonstrated that the pre-, intraand postoperative combined with hemofilter could protect the SIRS incidence at 3 and 24 postoperative. 
TABLE 1 . Baseline characteristic of the patients with open heart surgery

\begin{tabular}{|c|c|c|c|c|}
\hline Variable & $\begin{array}{c}\text { Group A }[\mathrm{n}(\%)] \\
{[48(50.5)]}\end{array}$ & $\begin{array}{c}\text { Group B [n (\%)] } \\
{[47(49.5)]}\end{array}$ & $\begin{array}{c}\text { Total }[\mathrm{n}(\%)] \\
{[95(100)]}\end{array}$ & $\mathrm{p}$ \\
\hline \multicolumn{5}{|l|}{ Age (Years) } \\
\hline$\geq 30$ & $39(81.3)$ & $41(87.2)$ & $80(84.2)$ & \multirow{2}{*}{0.451} \\
\hline$<30$ & $9(18.7)$ & $6(12.8)$ & $15(15.8)$ & \\
\hline \multicolumn{5}{|l|}{ Sex } \\
\hline Male & $26(54.2)$ & $22(46.8)$ & $48(50.5)$ & \multirow{2}{*}{0.473} \\
\hline Female & $22(45.8)$ & $25(53.2)$ & $47(49.5)$ & \\
\hline \multicolumn{5}{|l|}{ NYHA class } \\
\hline Two & $33(68.8)$ & $27(57.4)$ & $60(63.2)$ & \multirow{3}{*}{0.239} \\
\hline Three & $15(31.3)$ & $18(38.3)$ & $33(34.7)$ & \\
\hline Four & 0 & $2(4.3)$ & $2(2.1)$ & \\
\hline \multicolumn{5}{|l|}{$\mathrm{Hb}$} \\
\hline Abnormal & $3(6.7)$ & $1(2.3)$ & $4(4.5)$ & \multirow{2}{*}{0.617} \\
\hline Normal & $42(93.3)$ & $42(97.7)$ & $84(95.5)$ & \\
\hline \multicolumn{5}{|l|}{ Creatinine } \\
\hline Abnormal & $19(42.2)$ & $15(35.7)$ & $34(39.1)$ & \multirow{2}{*}{0.534} \\
\hline Normal & $26(57.8)$ & $27(64.3)$ & $53(60.9)$ & \\
\hline \multicolumn{5}{|l|}{ Ureum } \\
\hline Abnormal & $7(16.3)$ & $2(4.7)$ & $9(10.5)$ & \multirow{2}{*}{0.156} \\
\hline Normal & $36(83.7)$ & $41(95.3)$ & 77 (89.5) & \\
\hline \multicolumn{5}{|l|}{ Albumin } \\
\hline Abnormal & $3(6.7)$ & $4(9.5)$ & $7(8)$ & \multirow{2}{*}{0.707} \\
\hline Normal & $42(93.3)$ & $38(90.5)$ & $80(92)$ & \\
\hline \multicolumn{5}{|l|}{$\begin{array}{l}\text { Blood glucose } \\
\text { level }\end{array}$} \\
\hline Abnormal & $3(6.8)$ & $7(16.7)$ & $10(11.6)$ & \multirow{2}{*}{0.191} \\
\hline Normal & $41(93.2)$ & $35(83.3)$ & $76(88.4)$ & \\
\hline \multicolumn{5}{|l|}{ Kalium } \\
\hline Abnormal & $4(9.3)$ & $2(4.8)$ & $6(7.1)$ & \multirow{2}{*}{0.676} \\
\hline Normal & $39(90.7)$ & $40(95.2)$ & 79 (92.9) & \\
\hline \multicolumn{5}{|l|}{ Natrium } \\
\hline Abnormal & $5(11.6)$ & $2(4.8)$ & $7(8.2)$ & \multirow{2}{*}{0.433} \\
\hline Normal & $38(88.4)$ & $40(95.2)$ & 78 (91.8) & \\
\hline \multicolumn{5}{|l|}{ Magnesium } \\
\hline Abnormal & $2(4.9)$ & $6(16.7)$ & $8(10.4)$ & \multirow{2}{*}{0.137} \\
\hline Normal & $39(95.1)$ & $30(83.3)$ & $69(89.6)$ & \\
\hline \multicolumn{5}{|l|}{ Calcium } \\
\hline Abnormal & 0 & $3(8.3)$ & $3(4)$ & \multirow{2}{*}{0.106} \\
\hline Normal & $39(100)$ & 33 (91.7) & $72(96)$ & \\
\hline
\end{tabular}


Supomo et al., The effect of combination of hemofilter, pre- and intraoperative methylprednisolone administration on systemic inflammatory response syndrome (SIRS) post open heart surgery

TABLE 2. The incidence [n (\%)] of SIRS at 3 hours post surgery

\begin{tabular}{|c|c|c|c|c|c|}
\hline Treatment Group & $\begin{array}{c}\text { Yes } \\
66(69.5)\end{array}$ & $\begin{array}{c}\text { No } \\
29(30.5)\end{array}$ & $\begin{array}{c}\text { Total } \\
95(100)\end{array}$ & OR $(95 \% \mathrm{CI})$ & $\mathrm{p}$ \\
\hline Group A & $24(36.4)$ & $24(82.8)$ & $48(50.5)$ & \multirow{2}{*}{$0.12(0.03-0.39)$} & \multirow{2}{*}{$<0.001$} \\
\hline Group B & $42(63.6)$ & $5(17.2)$ & $47(49.5)$ & & \\
\hline
\end{tabular}

$\mathrm{RRR}=0.44(0.245-0.585) ; \mathrm{ARR}=0.394(0.212-0.542) ; \mathrm{NNT}=2(5-2)$

TABLE 3. The incidence of SIRS at 24 hours post surgery

\begin{tabular}{lccccc}
\hline \multicolumn{1}{c}{ Treatment Group } & Yes & No & Total & OR $(95 \%$ CI $)$ & p \\
& $58(63.7)$ & $33(36.3)$ & $91(100)$ & & \\
\hline Group A & $25(43.1)$ & $22(66.7)$ & $47(51.6)$ & $0.38(0.14-1.00)$ & $<0.001$ \\
Group B & $33(56.9)$ & $11(33.3)$ & $44(48.4)$ & & \\
\hline
\end{tabular}

$\mathrm{RRR}=0.291(0.025-0.484) ; \mathrm{ARR}=0.218(0.021-0.392) ; \mathrm{NNT}=4(49-3)$

Table 4. The incidence of post-operative SIRS in group A and group B

\begin{tabular}{|c|c|c|c|c|c|c|c|c|c|c|c|c|}
\hline \multirow{3}{*}{$\begin{array}{l}\text { Treatment } \\
\text { Group }\end{array}$} & \multicolumn{12}{|c|}{ Hours post-operative } \\
\hline & \multicolumn{3}{|c|}{3 -hours $(n=66)$} & \multicolumn{3}{|c|}{ 24-hours $(\mathrm{n}=58)$} & \multicolumn{3}{|c|}{ 48-hours $(n=33)$} & \multicolumn{3}{|c|}{ 72-hours $(n=9)$} \\
\hline & $\begin{array}{l}\text { SIRS } \\
{[\mathrm{n}(\%)]}\end{array}$ & $\begin{array}{c}\text { OR } \\
(95 \% \\
\text { CI })\end{array}$ & $\mathrm{p}$ & $\begin{array}{l}\text { SIRS } \\
{[\mathrm{n}(\%)]}\end{array}$ & $\begin{array}{c}\text { OR } \\
(95 \% \\
\text { CI })\end{array}$ & $\mathrm{p}$ & SIRS (n) & $\begin{array}{l}\text { OR } \\
(95 \% \\
\text { CI) }\end{array}$ & $\mathrm{p}$ & $\begin{array}{c}\text { SIRS } \\
{[\mathrm{n}(\%)]}\end{array}$ & $\begin{array}{c}\text { OR } \\
(95 \% \\
\text { CI })\end{array}$ & $\mathrm{p}$ \\
\hline Group A & $24(36.4)$ & & & $25(43.1)$ & & & $17(51.5)$ & & & $6(66.7)$ & & \\
\hline Group B & $42(63.6)$ & $\begin{array}{c}8.40 \\
(2.835- \\
24.89)\end{array}$ & $<0.001$ & $33(56.9)$ & $\begin{array}{c}2.64 \\
(1.08- \\
6.44)\end{array}$ & 0.031 & $16(48.5)$ & $\begin{array}{c}1.01 \\
(0.427- \\
2.391)\end{array}$ & 0.980 & $3(33.3)$ & $\begin{array}{c}0.50 \\
(0.12- \\
2.155)\end{array}$ & 0.485 \\
\hline
\end{tabular}

\section{DISCUSSION}

In this study, the lower SIRS incidence in group A than group B was observed. Some factors are associated with SIRS in open heart surgery including surgical trauma and extracorporal circulation. ${ }^{2}$ Major surgical trauma in open heart surgery procedure is thoracotomy and surgical incisions on blood vessels and heart. The major surgical trauma can trigger cytokine release to the blood circulation and lead to SIRS. ${ }^{14-16}$ Methylprednisolone administration may inhibit the synthesis of cytokines. Moreover, it may stabilize pro-inflammatory and anti-inflammatory cytokines which results in reducing risk of
SIRS. ${ }^{17,18}$ Extra corporeal circulations in cardiopulmonary bypass machine allows contact of blood and inner machine circuit which will affect complement system, platelet, endothelial cell, neutrophil, and monocyte. Circulating cytokines can activate those components resulting in SIRS. ${ }^{19,20}$ Hemofilter installment in cardiopulmonary bypass machine is reported to reduce the level of circulating cytokine ${ }^{21}$ moreover reduce the risk of SIRS incidence.

The most significantly different in SIRS incidence between Group A and Group B was observed at 3 hours post surgery in this study. This result demonstrated that 
the optimal effect of methylprednisolone in the decrease SIRS incidence occurred mostly at 3 hours postsurgery. The maximum serum pro-inflammatory cytokines and complement levels in patients undergoing cardiopulmonary bypass was achieved 3 hours after the extracorporal circulation stopped. ${ }^{22}$ It means that the highest SIRS incidence can be occurred at several hours after the extracorporal circulation stopped and when the high serum pro-inflammatroy cytokines achieved. Furthermoore, the serum pro-inflammatory declines gradually during 24 hours postsurgery followed by the decrease of SIRS incidence. In addition, with the methyprednisoone half life of 6-12 hours and its time peak serum concentration of 1-2 hours $^{23}$, the maximal protection effect of methylprednisolone against SIRS is achieved at several hours after administration.

No difference of SIRS incidence between group A and B at 48 and 72 hours postsurgery was observed in this study. It might be explained by the fact that after 48 and 72 hours postsurgery, the serum methylprednisolone concentration does not achieved therapeutic range concentration, therefore it does not have protection effect against SIRS. Furthermore, the use of hemofilter has been stopped.

\section{CONCLUSION}

In conclusion, pre- and intraoperative methylprednisolone administration combined the use hemofilter in open heart surgery significantly decrease the SIRS incidence.

\section{ACKNOWLEDGEMENTS}

We would like to thank all patients who have participated in this study.

\section{REFERENCES}

1. Cremer J, Martin M, Redl H, Bahrami S, Abraham C, Graeter T. Systemic inflammatory response after cardiac surgery. Ann Thorac Surg 1996; 61: 1714-20. https://doi.org/10.1016/0003-4975(96) 00055-0

2. Sablotzki A, Mühling J, Dehne MG, Zickmann B, Silber SE, Friedric I. et al. Treatment of sepsis in cardiac surgery: role of immunoglobulins. Perfusion 2001; 16: 11320.

https://doi.org/10.1177/02676591010160 0205

3. Drago A. 2007. Systemic Inflammatory Response Syndrome (SIRS) after Cardiac surgery. [cited 2016, September 5]. Availale from: www.fac.org.ar/qcvc/llavc/c130i/ dragoa.php

4. Kirklin JK \& McGriffin DC. Early complication following cardiac surgery. Cardivasc Clin 1987; 17(3):321-43.

5. Kirklin JK. Prospects for understanding and eliminating the deleterious effects of cardiopulmonary bypass. Ann Thorac Surg 1991; 51(4): 529-31.

https://doi.org/10.1016/0003-4975(91) 90302-7

6. Reploge RL, Glazzaniga AB, Gross RE. Use of corticosteroids during cardiopulmonary bypass: possible lysosome stabilization. Circulation 33: 186-91 (suppl 1).

7. Dietzman RH, Lunseth JB, Goott B, Berger E. The use of methylprednisolon during cardiopulmonary bypass. J Thorac Cardiovasc Surg 1975; 69(6): 870-3.

8. Chaney MA. Corticosteroids and cardiopulmonary bypass: a review of clinical investigation. Chest 2002; 12(3): 921-31. https://doi.org/10.1378/chest.121.3.921

9. Robertson-Malt S, Afrane B, El Barbary M. Prophylactic Steroid for Pediatric Open Heart Surgery. Cochrane Database Syst Rev 2007; 17(4): CD005550 https://doi.org/10.1002/14651858.cd005550. pub2 
Supomo et al., The effect of combination of hemofilter, pre- and intraoperative methylprednisolone administration on systemic inflammatory response syndrome (SIRS) post open heart surgery

10. Graham EM. The utility of steroids in pediatric cardiac opertions. Pediatr Crit Care Med 2014; 15(5): 492-3. DOI:10.1097/ PCC. 0000000000000139

https://doi.org/10.1097/PCC.0000000000000 139

11. Sutton RG \& Rothenberg D. Ultrafiltration and dialysis. In: Gravlee GP, Davis RF, Stammers AH, Ungerleider RM, editors. Cadiopulmonary bypass: principle and practice, 3th ed. Philadelphia: Lippicott Willian \& Wilkins, 2008.

12. Moore RA \& Laub GW. Hemofiltration, dialysis, and blood salvage techniques during cardiopulmonary bypass In: Gravlee GP, Davis RF, Kurusz M, Utley JR, editor. Cadiopulmonary bypass: principle and practice, 2nd ed. Philadelphia: Lippicott Willian \& Wilkins, 2000.

13. Grunenfelder J, Zund G, Schoeberlein A, Malay FE, Schurr U, Guntli S, et al. Modified ultrafiltration lowers adhesion molecule and cytocain level after cardiopulmonary bypass without clinical relevance in adults. Eur J Cardiothorac Surg 2000; 17(1): 77-83. https://doi.org/10.1016/S1010-7940(99) 00355-3

14. Brochner AC, Toft P. Pathophysiology of the inflammatory response after major accidental trauma. Scand J Trauma Resusc Emerg Med 2009; 17: 43. DOI: 10.1186/1757-7241-1743.

https://doi.org/10.1186/1757-7241-17-43

15. Biffl WF, Moore EE, Moore FA, Peterson VM. Interleukin- 6 in the injured pasient. marker of injury or mediator of inflammtion? Annal of Surgery 1996; 224(5):647-64. https://doi.org/10.1097/00000658199611000-00009

16. Mokart D, Merlin M, Sannini A, Brun JP, Delpero JR, Houvenaeghel G, et al. Procalcitonin, interleukin 6 and systemic inflammatory response syndrome (SIRS): early markers of postoperative sepsis after major surgery. Br J Anaesth 2005; 94: 767-73. https://doi.org/10.1093/bja/aei143

17. Rhen $\mathrm{T}$ and Cidlowski JA. Antiinflammatory action of glucocorticoid new mechanism for old drugs. N Engl J Med 2005; 353(16): 1711-23. https://doi.org/10.1056/NEJMra050541

18. Chaney MA. Corticosteroids and cardiopulmonary bypass: a review of clinical investigation. Chest 2002; 121: 921-31. https://doi.org/10.1378/chest.121.3.921

19. Esper RJ, Nordaby RA, Vilarino JO, Paragano A, Cacharron JL, Machado RA, et al. The endothelial disfunction: a comprehensive appraisal. Cardivasc Diabetol 2006; 5:4. DOI:10.1186/1475-2840-5-4 https://doi.org/10.1186/1475-2840-5-4

20. Menasche PI and Edmunds LH. The inflammatory response. In: Cohn LH, editor. Cardiac surgery in the adult, 3rd ed. New York: McGraw-Hill, 2003.

21. Tassani, P, Richter JA, Eising GP, Barankay A, Braun SL, Haehnel CH, et al. Influence of combined zero-balanced and modified ultrafiltration on the systemic inflamatory response during coronary artery bypass grafting. J Cardiothorac Vasc Anesth 1999; 13(3): 285 - 91. DOI: 10.1016/S10530770(99)90265-3

https://doi.org/10.1016/S1053-0770(99) 90265-3

22. Steinberg JB, Kapelanski DP, Olson JD, Weiler JM. Cytokine and complement levels in patients undergoing cardiopulmonary bypass. J Thorac Cardiovasc Surg 1993; 106(6):1008-1016.

23. Annane D, Sebille V, Charpentier C, Bollaert PE, Françoise B, Korach JM, et al. Effect of treatment with low doses of hidrocortisone and fludrocortisone on mortality in patients with septic shock. JAMA 2002; 288(7): 86271.

https://doi.org/10.1001/jama.288.7.862 